\title{
Role of C-Reactive Protein (CRP) in the Prediction of Anastomotic Leakage Following Gastrointestinal Surgery
}

\author{
Dr. MD Afsar Alam, Dr. MD Aftab Ahmed ${ }^{2}$, Dr. Rajesh Kumar ${ }^{3}$, Dr. R G Baxla ${ }^{4}$ \\ ${ }^{1,2,3}$ Rajendra Institute of Medical Sciences, Ranchi, Jharkhand, India
}

${ }^{4}$ Professor, Rajendra Institute of Medical Sciences, Ranchi, Jharkhand, India

\begin{abstract}
Anastomotic leak following gastrointestinal surgery is the most serious postoperative complication. ${ }^{1}$ Anastomotic leakage was defined clinically by peritonitis resulting from the leakage, with signs of acute abdomen (fever, sepsis, pain abdomen), and suspicious quality or fecal discharge from drain wound is present. ${ }^{2}$ Surgeons lack predictive accuracy for anastomotic leakage in gastrointestinal surgery. ${ }^{3}$ Routine imaging is neither reliable nor cost-effective for the detection of leaks and it carries the drawback of radiation. A serum marker would have great advantages provided that it is cost-effective and sensitive enough to allow safe discharge of the patient. ${ }^{4} C$-reactive protein (CRP) has been used for the diagnosis of intra-abdominal surgical infection, as a general marker of an unfavorable postoperative course including surgical and non surgical complication. ${ }^{5-7}$ Anastomotic leakage increases the duration of inhospital stay, the risk of reoperation and also can lead to a fatal outcome. Systemic inflammation markers, including $C$-reactive protein (CRP) and white cell count, have been reported to provide early detection. However, their relative predictive value is unclear. The median normal concentration of CRP is $0.8 \mathrm{mg} / \mathrm{l}$, with $90 \%$ of apparently healthy individual having value less than $3 \mathrm{mg} / \mathrm{l}$ and $99 \%$ less than $12 \mathrm{mg} / \mathrm{l}$. So, the reference range for CRP is: $0-10 \mathrm{mg} / \mathrm{l} .{ }^{8} \mathrm{C}$-reactive protein greater than $14 \mathrm{mg} / \mathrm{l}$ is sensitive and specific marker for anastomotic leak. C-reactive protein (CRP) test is done to check for infection after surgery. CRP levels normally rise within 2 to 6 hours of surgery and then go down by the third day after surgery. If CRP levels stay elevated 3 days after surgery, an infection may be present. Normal CRP values vary from lab to lab. Generally, there is no CRP detectable in the blood or there is little CRP in blood serum. The normal level of CRP is less than $10 \mathrm{mg} / \mathrm{dl}$, and patient who have elevation greater than $150 \mathrm{mg} / \mathrm{dl}$, usually have severe disease. Creactive protein $(C R P)$ is an acute phase protein synthesized by the liver, which levels raise in response to inflammation. ${ }^{9}$ It is a member of the pentraxin family of proteins. ${ }^{10}$ Human serum contains two pentraxins, c-reactive protein (CRP) and serum amyloid $p$ component $(S A P)$, are located on the proximal long arm of chromosome $1 .{ }^{11}$ C-reactive protein was the first pattern recognition receptor (PRR) to be identified. ${ }^{10}$ It has 224 amino acids, ${ }^{11}$ has a monomer molecular mass of $25106 \mathrm{Da}$, The most striking difference between CRP and $S A P$ is manifested during the acute phase response to inflammation. Whereas human SAP is expressed constitutely at relatively constant serum levels, C-reactive protein increases in concentration by up to 1000-fold in response to an inflammatory stimulus. C-reactive protein originally identified as a component present in the plasma of patients with acute infections, binds to the c-polysaccharide of streptococcus pneumoniae. Subsequently, it has been shown to have several immune related activities, for opsonisation of bacterial cell surfaces and activation of complement and to act as a scavenger for chromatin released by dead cells during inflammatory episodes. It plays a role in innate immunity as an early defense system against infections. CRP rises within two hours of the onset of inflammation, up to a 50,000-fold, and peaks at 48 hours. Its half-life of 48 hours is constant, and therefore its level is determined by the rate of production and hence the severity of the precipitating cause. CRP is thus a screen for inflammation. CRP is used mainly as a marker of inflammation. Apart from liver failure, there are few known factors that interfere with CRP production. ${ }^{9}$ Measuring and charting CRP values can prove useful in determining disease progress or the effectiveness of treatments. ELISA, immunoturbidimetry, rapid immunodiffusion and visual agglutination are all methods used to measure CRP. A high-sensitivity CRP (hs-CRP) test measures low levels of CRP using laser nephelometry. The test gives results in 25 minutes with sensitivity down to $0.04 \mathrm{mg} / \mathrm{L}$. CRP is not diagnostic of any condition, but it can be used together with signs and symptoms and other tests to evaluate an individual for an acute or chronic inflammatory condition. CRP is a more sensitive and accurate reflection of the acute phase response than the ESR (Erythrocyte Sedimentation Rate). ${ }^{12}$ ESR may be normal and CRP elevated. CRP returns to normal more quickly than ESR in response to therapy. Some medications - such as birth control pills; statins; nonsteroidal anti-inflammatory drugs (NSAIDs), including ibuprofen (Advil, Motrin, others); and acetaminophen (Tylenol, others) - can affect your CRP level. Normal concentration in healthy human serum is usually lower than $10 \mathrm{mg} / \mathrm{L}$, slightly increasing with aging. Higher levels are found in late pregnant women, mild inflammation and viral infections $(10-40 \mathrm{mg} / \mathrm{L})$, active inflammation, bacterial infection $(40-200 \mathrm{mg} / \mathrm{L})$, severe bacterial infections and burns $(>200 \mathrm{mg} / \mathrm{L}) .{ }^{13}$ Due to its short half-life $(19 \mathrm{~h}), \mathrm{CRP}$ is a reliable marker of systemic inflammatory response secondary to the surgical procedure or even a marker of complications, tending to normalize rapidly with the patient's recovery. ${ }^{14-15}$
\end{abstract}

Keywords: Anastomotic leak, C-reactive protein, Systemic inflammation markers, pentraxin, serum amyloid p component, pattern recognition receptor, opsonisation, immunoturbidimetry, rapid immunodiffusion, visual agglutination

\section{Aims and Objectives}

1) To determine the reliability of $\mathrm{C}$ - reactive protein in predicting anastomotic leak following gastro-intestinal surgery.
2) To determine the efficacy of CRP in predicting early discharge and decreased length of hospital stay and hence overall cost. 


\section{International Journal of Science and Research (IJSR) \\ ISSN (Online): 2319-7064}

Index Copernicus Value (2015): 78.96 | Impact Factor (2015): 6.391

\section{Method}

A study will be conducted on 54 patients admitted in Rajendra Institute of Medical Sciences (RIMS), Ranchi from October 2013 to October 2014 and underwent surgery with primary gastro-intestinal anastomosis for whatsoever cause, either as elective or emergency cases. Serum C-reactive protein was measured preoperatively to have a baseline value in all cases; and then measured postoperative on alternate day starting from day one, and onwards till $5^{\text {th }}$ day. We assigned cases to one of two groups according to the presence or absence of anastomotic leakage: with anastomotic leakage (Group A, $n=6$ ), without anastomotic leakage (Group B, $\mathrm{n}=48$ ). The two groups were compared according to the mean values of serum CRP in the pre and postoperative period.

\section{Serums CRP up to $1.0 \mathrm{mg} / \mathrm{L}$ are considered normal value in our study.}

Inclusion criteria- All surgical cases with primary gastro intestinal anastomosis (Elective and Emergency)

Exclusion criteria- Presence of a defunctioning stoma

The following Protocols was followed-

Post operative patients were monitored every day. Signs of peritonitis were looked for; pulse, BP, temperature and urine output was recorded. These data was correlated with $\mathrm{C}$ reactive protein. A relationship with anastomotic leak, suggested by signs of peritonitis and deranged vitals was established.

If there were any signs suggestive of peritonitis and leakage found we did ultrasonography of the abdomen and correlated with them. A plan of further management decided upon presence or absence of leak

\section{Observations}

\section{Case Details}

CASE No.-

anastomosis-

Type of case -

Name of patient-

Reg. No \& Add. -

Age / Sex -

Pre-op

\begin{tabular}{|l|l|l|l|l|}
\hline Temp $\left({ }^{\circ} \mathrm{C}\right)$ & $\mathrm{PR}(\mathrm{min})$ & $\mathrm{BP}(\mathrm{mm} \mathrm{Hg})$ & $\mathrm{U} / \mathrm{O}(\mathrm{ml})$ & $\mathrm{CRP}(\mathrm{mg} / \mathrm{Lt})$ \\
\hline
\end{tabular}

Clinical course -

Post-op Day 01-

\begin{tabular}{|l|l|l|l|l|}
\hline Temp $\left({ }^{\circ} \mathrm{C}\right)$ & $\mathrm{PR}(\mathrm{min})$ & $\mathrm{BP}(\mathrm{mm} \mathrm{Hg})$ & $\mathrm{U} / \mathrm{O}(\mathrm{ml})$ & $\mathrm{CRP}(\mathrm{mg} / \mathrm{Lt})$ \\
\hline & & & & \\
\hline
\end{tabular}

Clinical course -

Post-op Day 03-

\begin{tabular}{|l|l|l|l|l|}
\hline Temp $\left({ }^{\circ} \mathrm{C}\right)$ & $\mathrm{PR}(\mathrm{min})$ & $\mathrm{BP}(\mathrm{mm} \mathrm{Hg})$ & $\mathrm{U} / \mathrm{O}(\mathrm{ml})$ & $\mathrm{CRP}(\mathrm{mg} / \mathrm{Lt})$ \\
\hline & & & & \\
\hline
\end{tabular}

Clinical course -
Post-op Day 05-

\begin{tabular}{|l|l|l|l|l|}
\hline Temp $\left({ }^{\circ} \mathrm{C}\right)$ & $\mathrm{PR}(\mathrm{min})$ & $\mathrm{BP}(\mathrm{mm} \mathrm{Hg})$ & $\mathrm{U} / \mathrm{O}(\mathrm{ml})$ & $\mathrm{CRP}(\mathrm{mg} / \mathrm{Lt})$ \\
\hline & & & & \\
\hline
\end{tabular}

Clinical course -

USG Finding -

Plan of $\mathrm{M} / \mathrm{m}-$

Table 1: Case Incidence

\begin{tabular}{|c|c|c|}
\hline Type of Case & No. of Cases & Percentage (\%) \\
\hline Elective & 33 & 61 \\
\hline Emergency & 21 & 39 \\
\hline Total & 54 & 100 \\
\hline
\end{tabular}

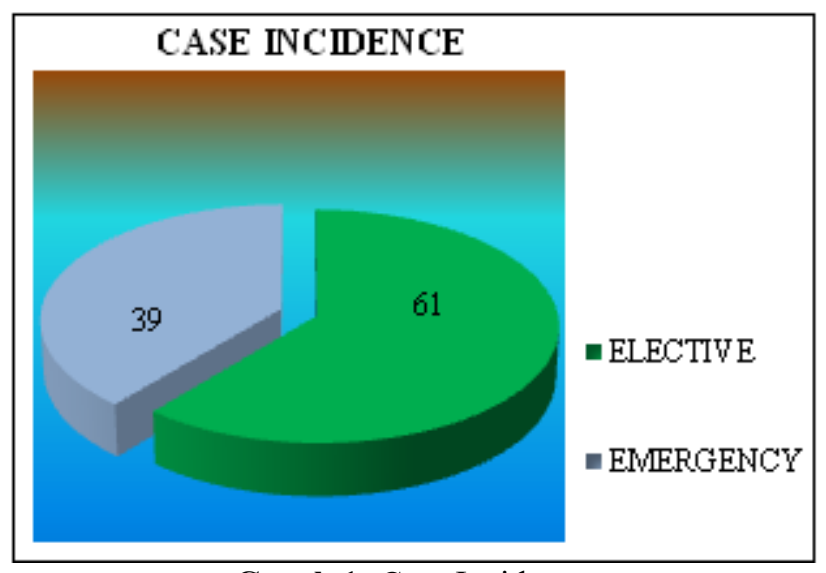

Graph 1: Case Incidence

Table 2: Sex incidence

\begin{tabular}{|c|c|c|}
\hline Sex & No. of Cases & Percentage (\%) \\
\hline Male & 34 & 63 \\
\hline Female & 20 & 37 \\
\hline Total & 54 & 100 \\
\hline
\end{tabular}

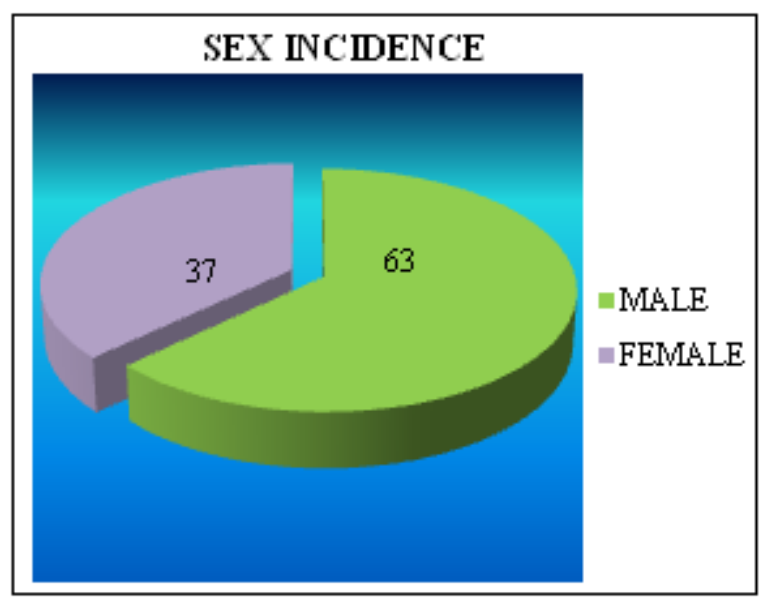

Graph 2: Sex incidence

Table 3: Age Distribution

\begin{tabular}{|c|c|}
\hline Age Group & No. of Patients \\
\hline $0-15$ & 6 \\
\hline $16-30$ & 14 \\
\hline $31-45$ & 16 \\
\hline $46-60$ & 16 \\
\hline $61-75$ & 2 \\
\hline TOTAL & 54 \\
\hline
\end{tabular}

Mean age- 40 years 


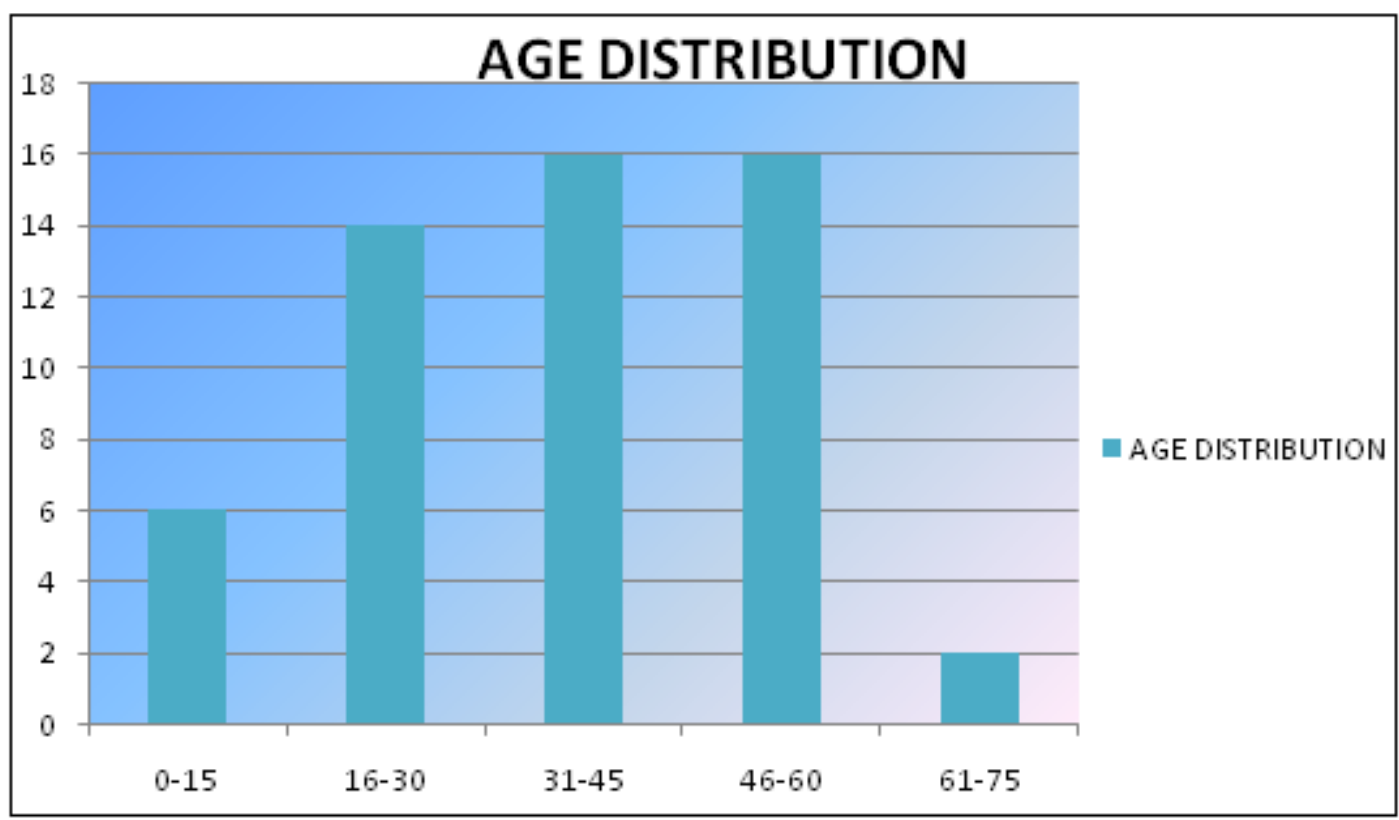

Graph 3: Age Distribution

Table 4: Type of Anastomosis

\begin{tabular}{|c|c|c|}
\hline Type of Anastomosis & No. of Cases & Percentage \\
\hline Gastro jejunostomy & 08 & 15 \\
\hline Jejuno ileal & 05 & 09 \\
\hline Ileo ileal & 21 & 39 \\
\hline Ileo colic & 16 & 30 \\
\hline Colo colic & 04 & 07 \\
\hline Total & 54 & 100 \\
\hline
\end{tabular}

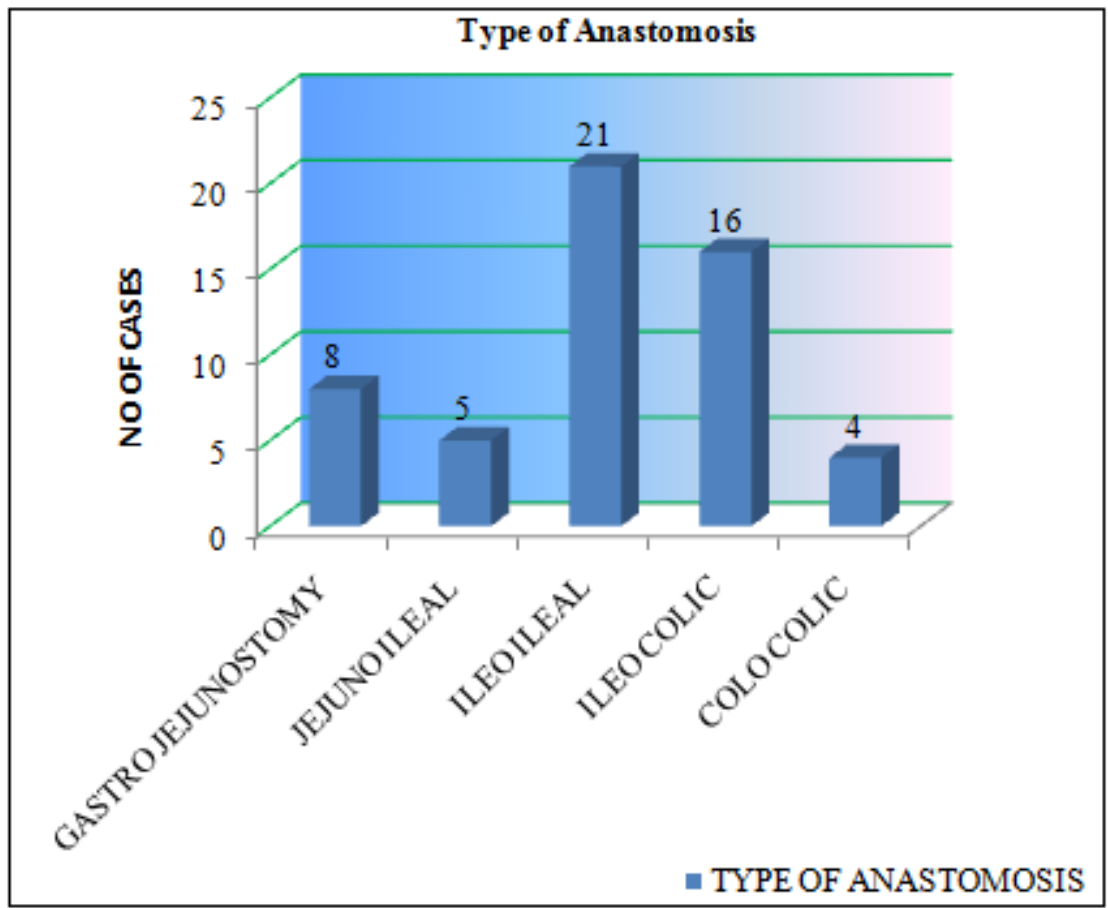

Graph 4: Type of Anastomosis

Table 5: No. of anastomotic leak in relation with site of anastomosis

\begin{tabular}{|c|c|}
\hline Type of Anastomosis & Number of Leak \\
\hline Gastrojejunostomy & 0 \\
\hline Jejunoileal & 1 \\
\hline Ileoileal & 4 \\
\hline Ileocolic & 1 \\
\hline Colocolic & 0 \\
\hline
\end{tabular}

Male - 04, Female -02

Mean age -37 years

Table 6: No. of cases leak in total

\begin{tabular}{|c|c|c|}
\hline Type of Case & No. of Cases Leak & Percentage (\%) \\
\hline Elective & 03 & 5.56 \\
\hline Emergency & 03 & 5.56 \\
\hline Total & 06 & 11.12 \\
\hline
\end{tabular}

Volume 6 Issue 1, January 2017

www.ijsr.net

Licensed Under Creative Commons Attribution CC BY 


\section{International Journal of Science and Research (IJSR) \\ ISSN (Online): 2319-7064}

Index Copernicus Value (2015): 78.96 | Impact Factor (2015): 6.391

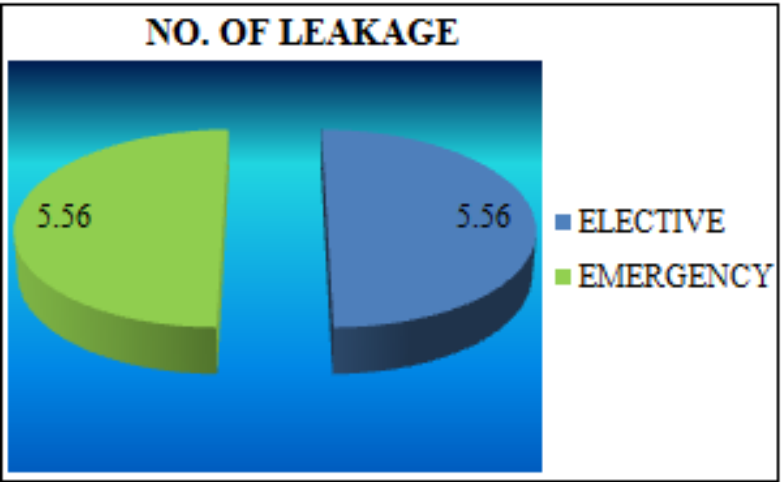

Graph 5: No. of leak cases in total

Table 7: No. of cases leak individually (elective and emergency)

\begin{tabular}{|c|c|c|c|}
\hline Type of Case & No. of Cases & No. of Leak Cases & Percentage (\%) \\
\hline Elective & 33 & 3 & 9 \\
\hline Emergency & 21 & 3 & 14 \\
\hline Total & 54 & 6 & 11 \\
\hline
\end{tabular}

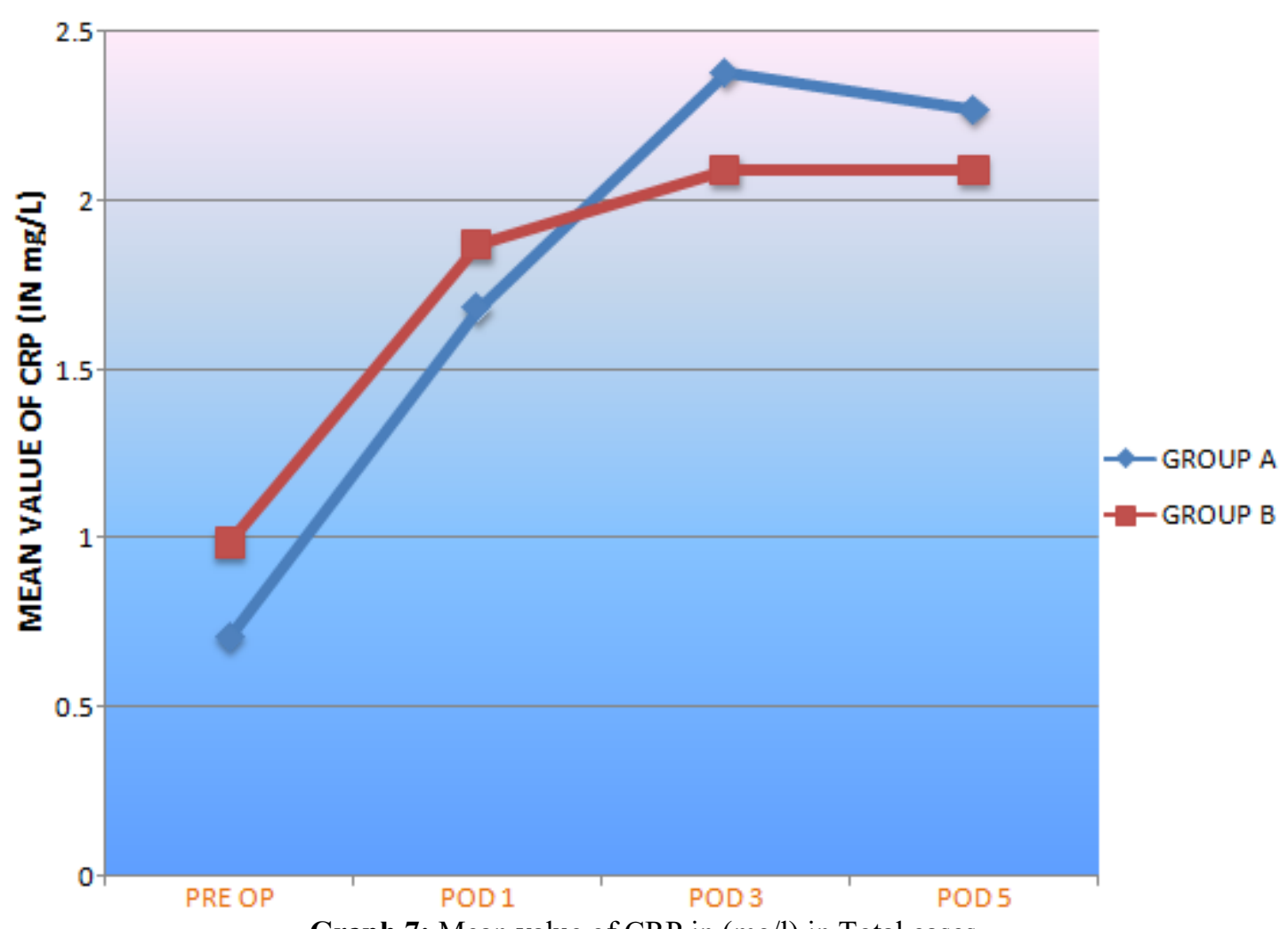

Graph 7: Mean value of CRP in (mg/l) in Total cases

Table 9: Mean values of CRP (mg/l) in the pre- and postoperative periods in Elective cases (Group I - with leakage; Group II - without leakage)

\begin{tabular}{|c|c|c|c|c|c|}
\hline Group I & 03 & 0.56 & 2.01 & 2.86 & 2.66 \\
\hline Group II & 30 & 0.89 & 1.86 & 2.0 & 2.06 \\
\hline Total & 33 & & & & \\
\hline
\end{tabular}

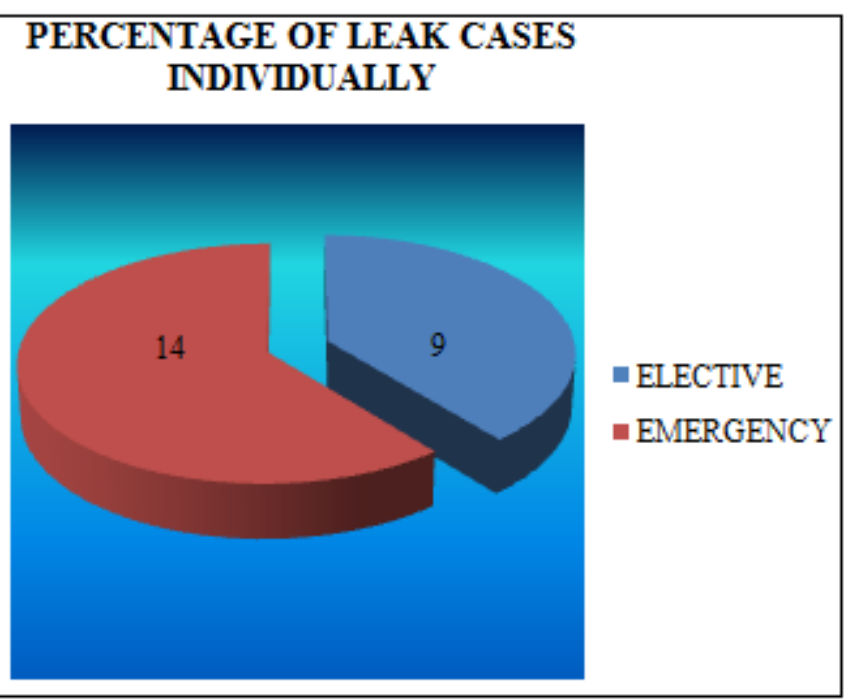

Graph 6: Percentage of leak cases individually

Table 8: Mean values of CRP (mg/l) in the pre- and postoperative periods in total cases. (Group A - with leakage; Group B - without leakage)

\begin{tabular}{|c|c|l|l|l|l|}
\hline CRP (mg/L) & No of Cases & Pre & POD 1 & POD 3 & POD 5 \\
\hline Group A & 6 & 0.71 & 1.68 & 2.38 & 2.27 \\
\hline Group B & 48 & 0.99 & 1.87 & 2.09 & 2.09 \\
\hline Total & 54 & & & & \\
\hline
\end{tabular}

\begin{tabular}{|l|l|l|l|l|} 
No. of Cases & PRE OP & POD 1 & POD 3 & POD 5 \\
\hline
\end{tabular}




\section{International Journal of Science and Research (IJSR) \\ ISSN (Online): 2319-7064}

Index Copernicus Value (2015): 78.96 | Impact Factor (2015): 6.391

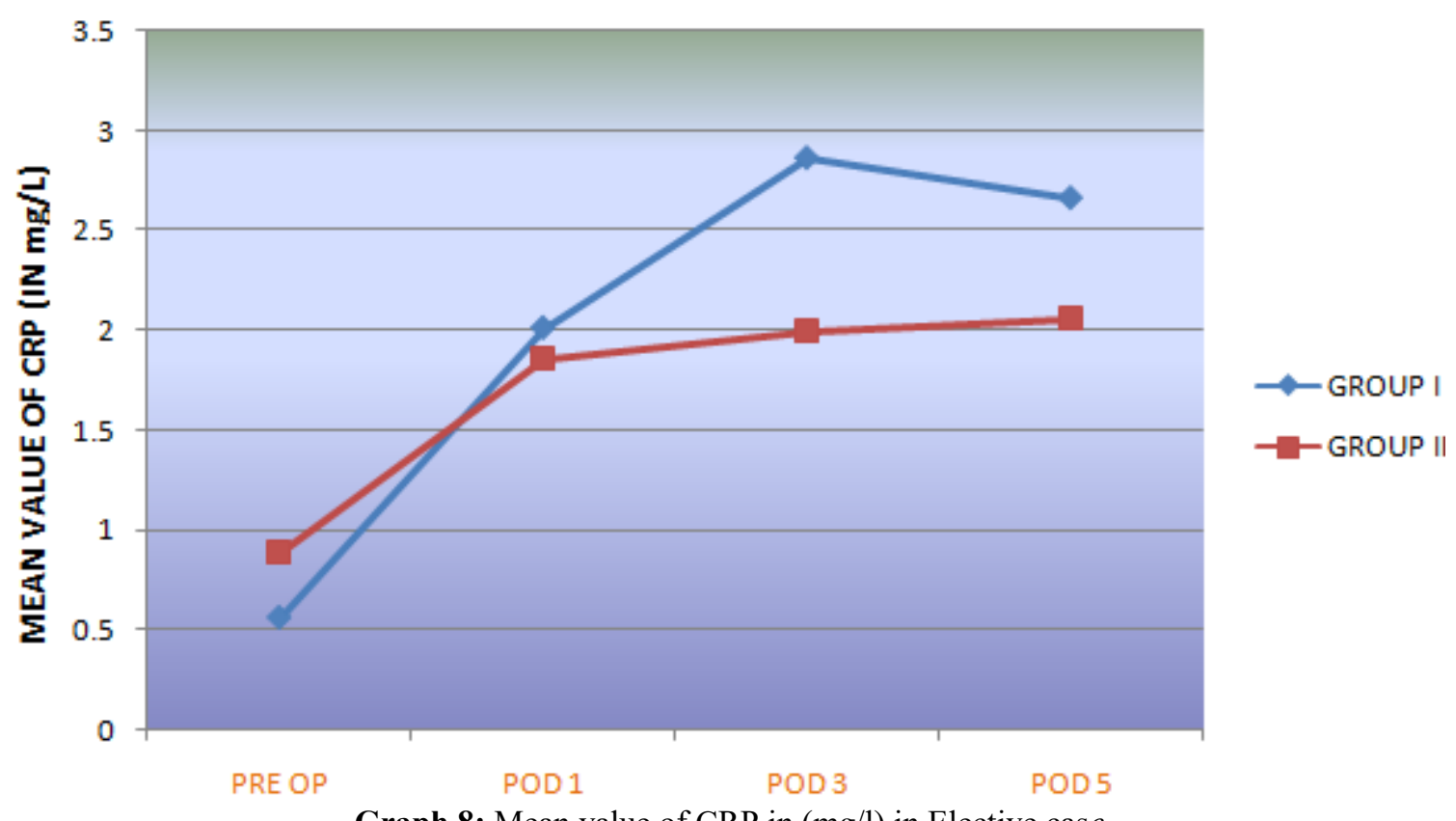

Graph 8: Mean value of CRP in ( $\mathrm{mg} / \mathrm{l})$ in Elective case

Table 10: Mean values of CRP (mg/l) in the postoperative periods in Emergency cases (Group X - with leakage; Group $\mathrm{Y}$ - without leakage)

\begin{tabular}{|c|c|c|c|c|c|}
\hline$C R P(\mathrm{mg} / \mathrm{L})$ & No. of Cases & PREOP & POD 1 & POD 3 & POD 5 \\
\hline Group X & 03 & 0.86 & 1.36 & 1.90 & 1.89 \\
\hline Group Y & 18 & 1.15 & 1.89 & 2.24 & 2.13 \\
\hline Total & 21 & & & & \\
\hline
\end{tabular}

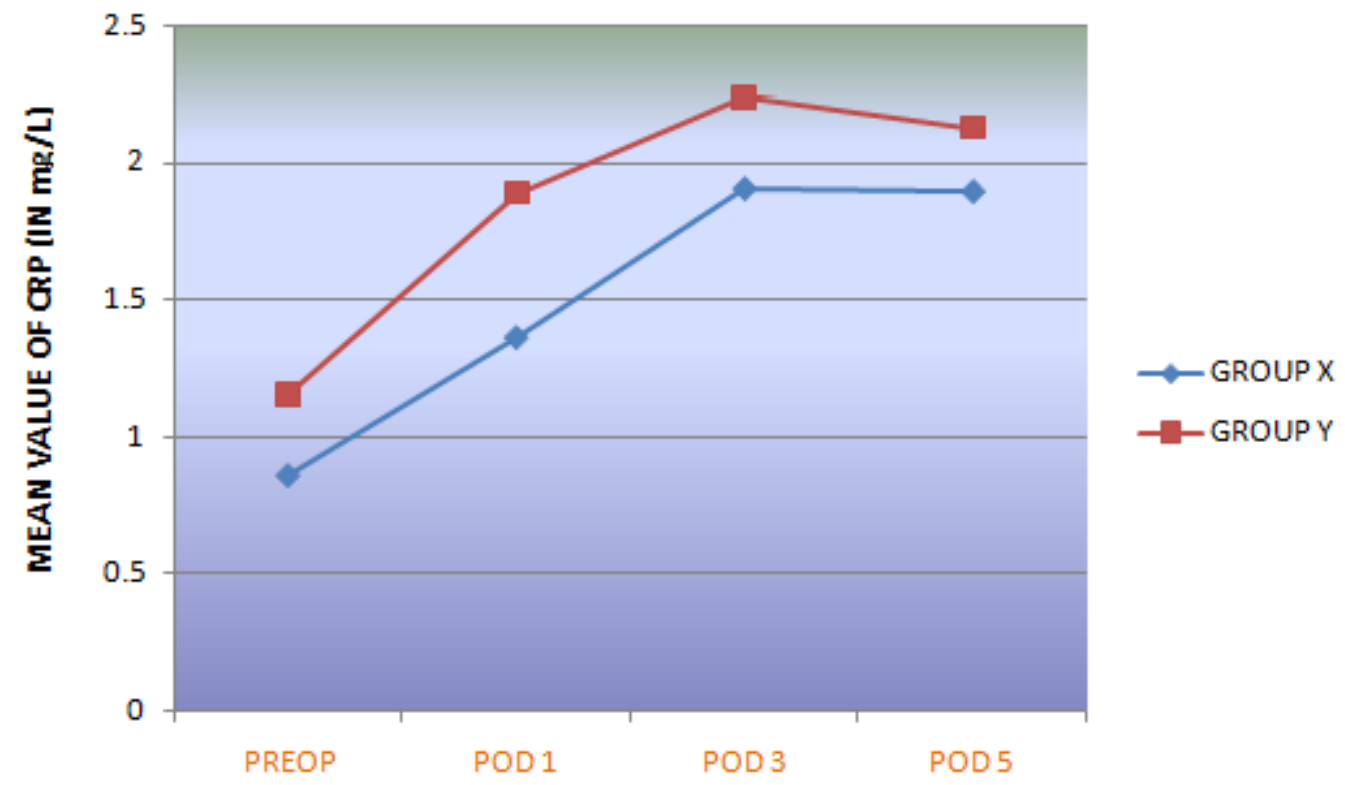

Graph 9: Mean value of CRP in (mg/l) in Emergency cases

Table 10: Various Ultrasonogrphy finding in leak cases

\begin{tabular}{|c|c|c|}
\hline S. No. & Usg Finding & No. of Cases \\
\hline 1 & Interseptate collection & 1 \\
\hline 2 & Pelvic collection & 2 \\
\hline 3 & Interseptate collectionwith pelvic collection & 1 \\
\hline 4 & Ascitis & 2 \\
\hline
\end{tabular}

Mean hospital stay of patients without leak- 7 days Mean hospital stay of patients with leak- 11 days

\section{Photographs Showing Various Types Of Anastomosis}

Table 11: Management given in leak cases

\begin{tabular}{|c|c|c|}
\hline S. No. & Management & No. of Cases \\
\hline 1 & Conservative & 5 \\
\hline 2 & Temporary stoma & 1 \\
\hline
\end{tabular}




\section{International Journal of Science and Research (IJSR)}

ISSN (Online): 2319-7064

\section{Gastrojejunostomy}
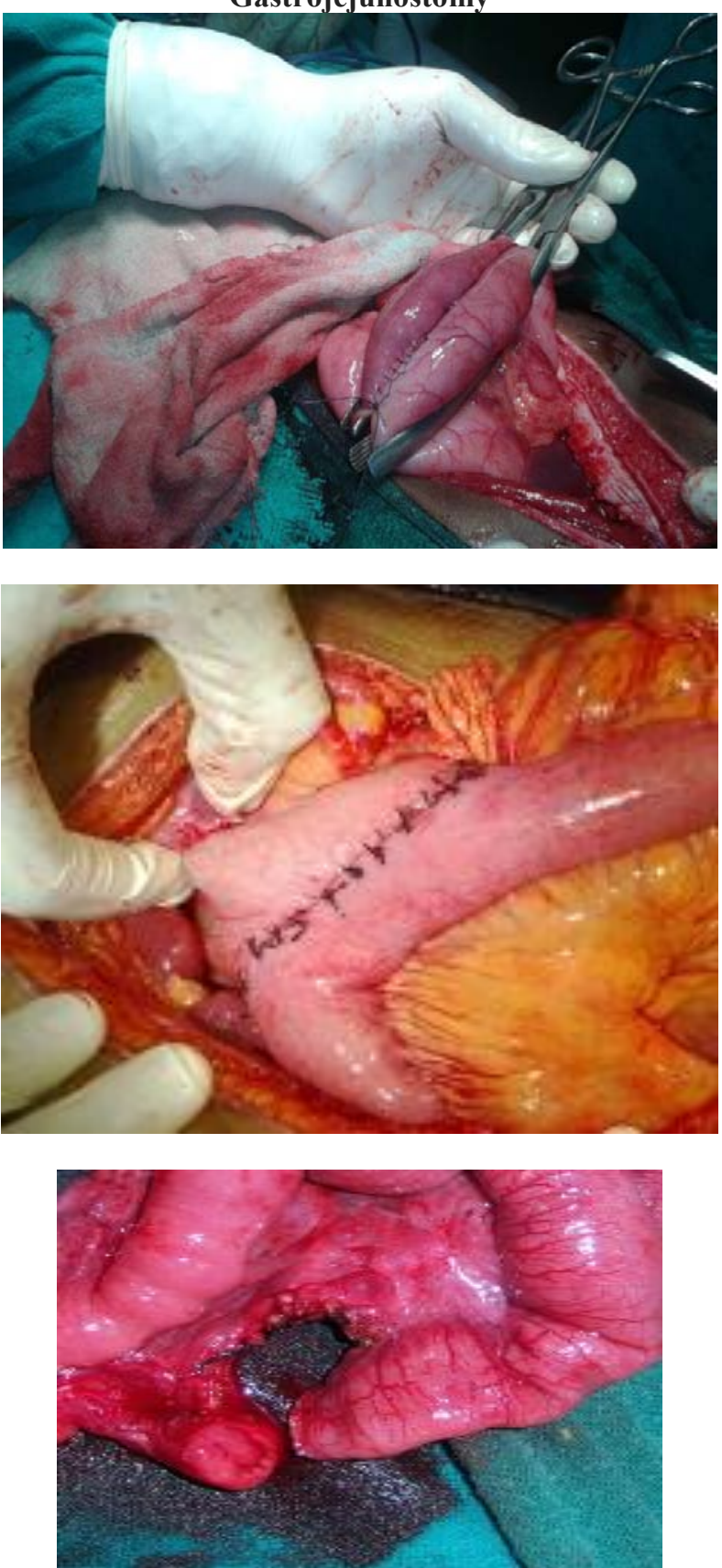

Jejunoileal Anastomosis

Volume 6 Issue 1, January 2017

www.ijsr.net 
International Journal of Science and Research (IJSR)

ISSN (Online): 2319-7064

Index Copernicus Value (2015): 78.96 | Impact Factor (2015): 6.391
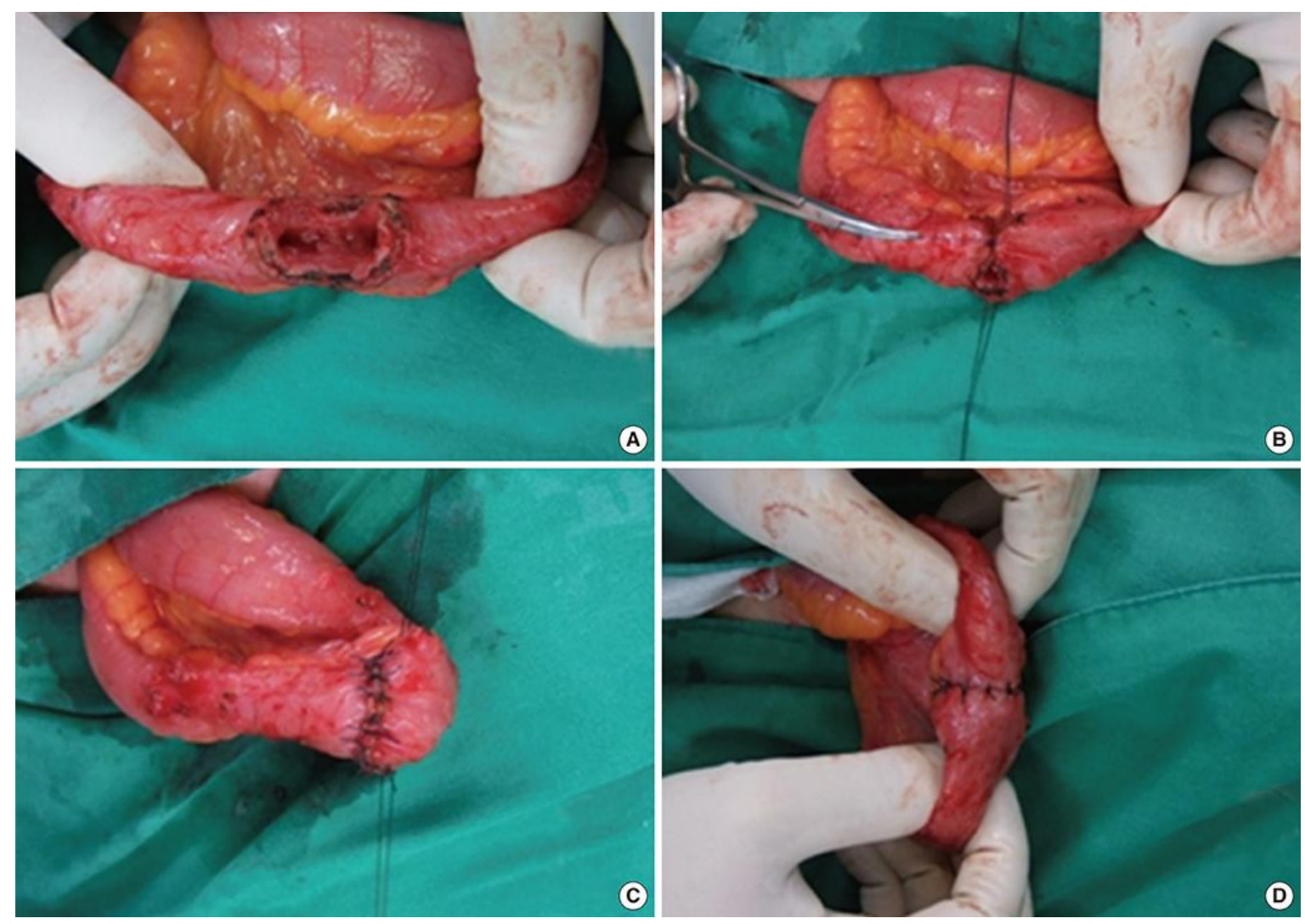

Ileostomy Closure

Ileoileal Anastomosis

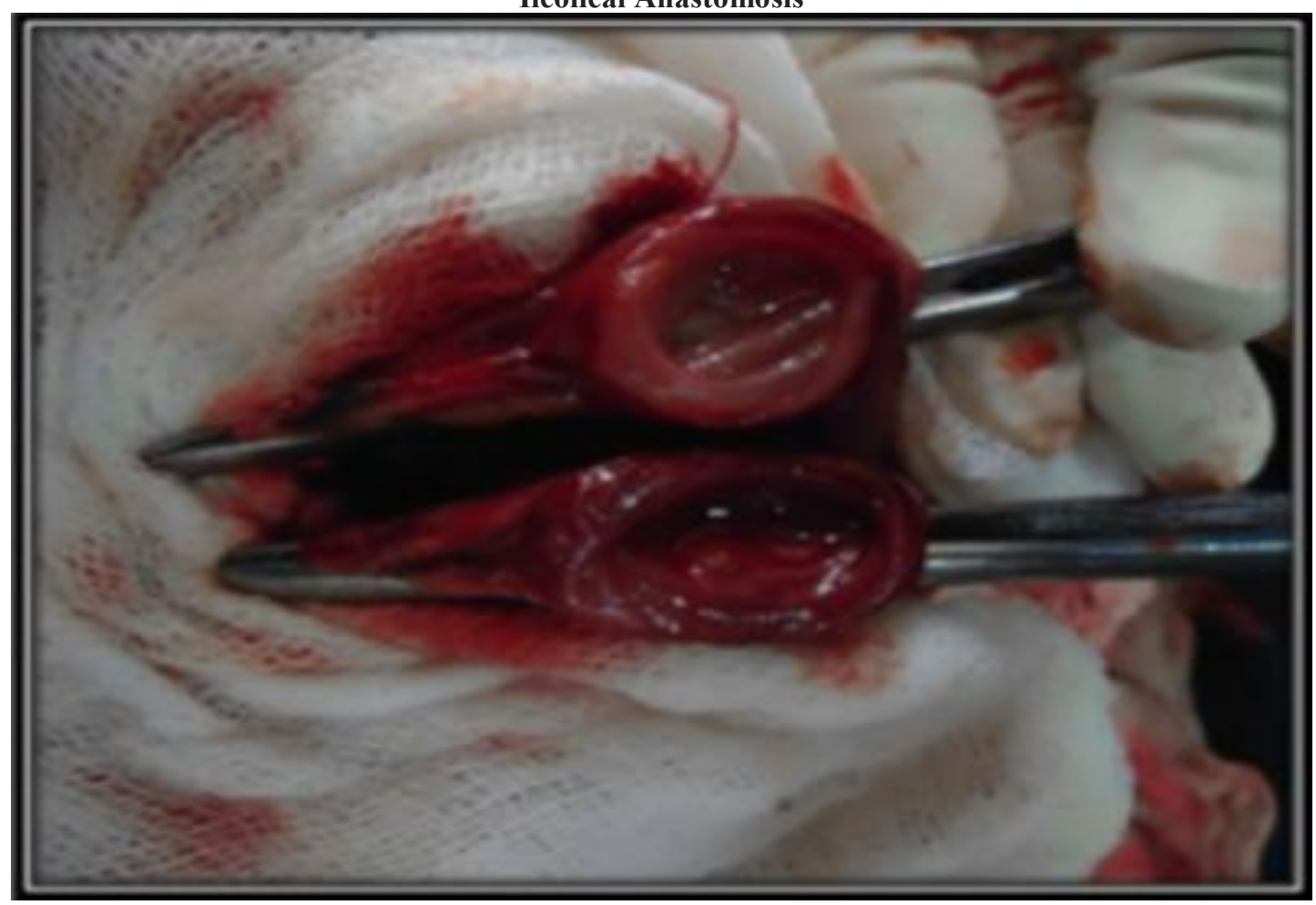

Volume 6 Issue 1, January 2017

www.ijsr.net

Licensed Under Creative Commons Attribution CC BY 


\section{International Journal of Science and Research (IJSR) \\ ISSN (Online): 2319-7064}

Index Copernicus Value (2015): 78.96 | Impact Factor (2015): 6.391

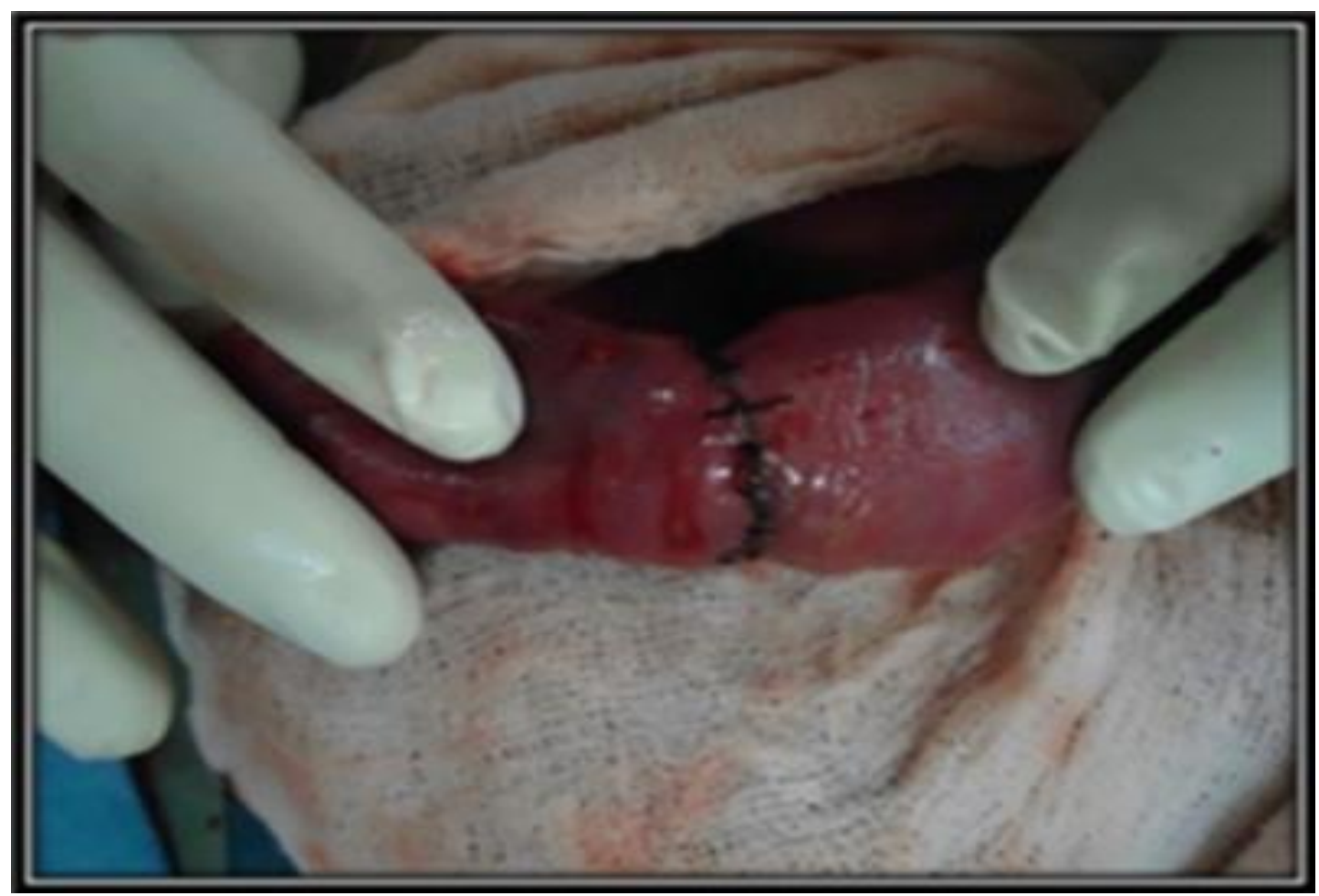

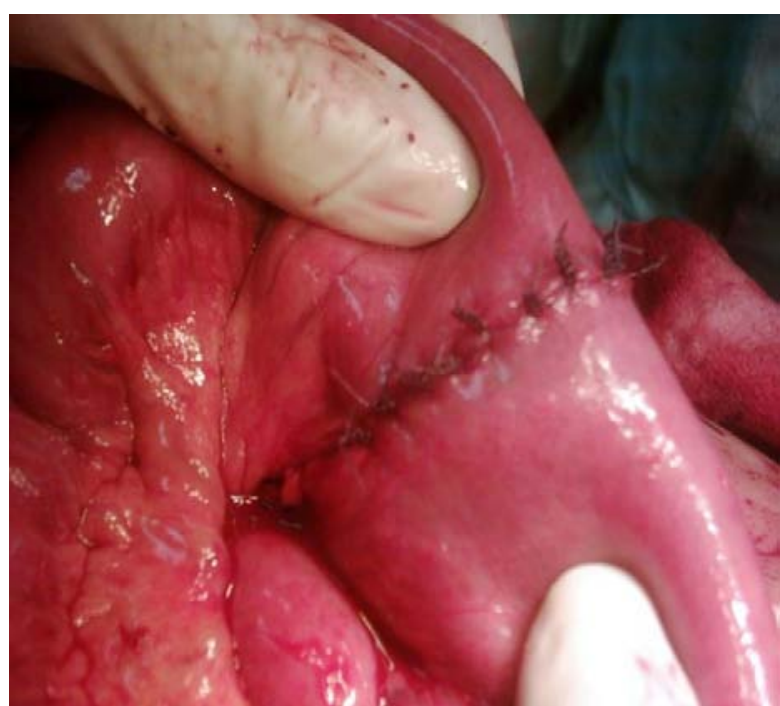

Ileocolic Anastomosis

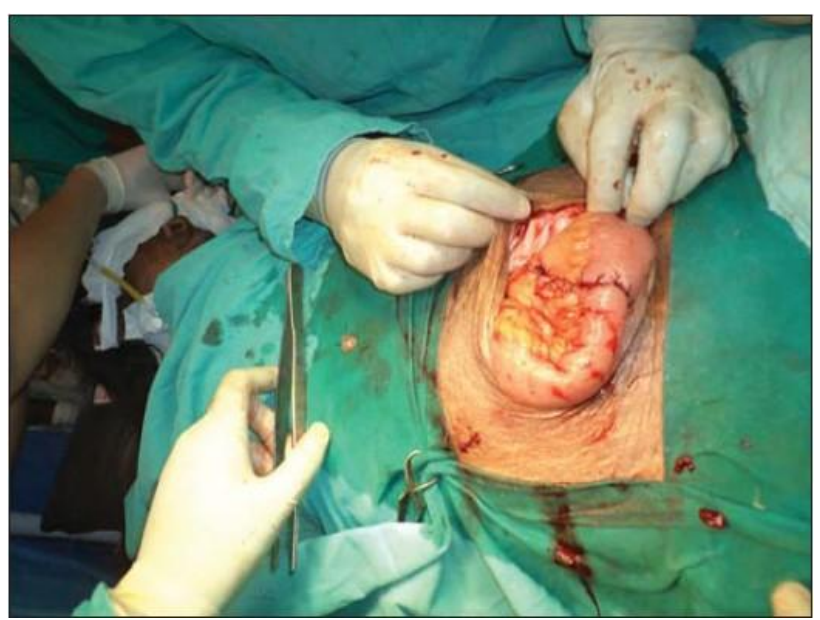

Colocolic Anastomosis

\section{Results}

A total of 54 patients underwent resection and anastomosis during the study period (oct.2013-oct.2014). Mean age was 40 years. Among 54 patients $34(63 \%)$ are male and 20 $(37 \%)$ are female. In this study we included 33 cases as elective and 21 cases as emergency. Leaks developed in 6 patients $(11 \%)$, including 4 males and 2 females. The mean age of patients with a leak was 37 years. The leak percentage was high in emergency cases (14) than in elective cases (9). The leak rate was markedly increased in ileoileal anastomosis (4 cases).

Mean values of CRP (mg/l) in the pre- and postoperative periods was higher in patients with leakage than in patients without leakage. Mean CRP was markedly increased from Preop to POD 1 and onwards (POD 3 and POD 5) in leaked cases, whereas mean CRP Is moderately increased from Preop to POD 3 and then onwards POD ( POD 5), CRP was either static or decreased in without leak cases.

After diagnosed by clinical suspicion and ultrasonography, 1 patient required fecal diversion by ileostomy, whereas 5 patients were managed non operatively.

Patients without leak were discharged earlier from hospital than patients with leak.

Mean hospital stay was longer for leaked patients (11 days) as compared to patients without leak (7 days).

\section{Discussion}

Some medications - such as birth control pills; statins; nonsteroidal anti-inflammatory drugs (NSAIDs), including ibuprofen (Advil, Motrin, others); and acetaminophen (Tylenol, others) — can affect your CRP level. 


\section{International Journal of Science and Research (IJSR) \\ ISSN (Online): 2319-7064 \\ Index Copernicus Value (2015): 78.96 | Impact Factor (2015): 6.391}

Normal concentration in healthy human serum is usually lower than $10 \mathrm{mg} / \mathrm{L}$, slightly increasing with aging. Higher levels are found in late pregnant women, mild inflammation and viral infections (10-40 mg/L), active inflammation, bacterial infection $(40-200 \mathrm{mg} / \mathrm{L})$, severe bacterial infections and burns $(>200 \mathrm{mg} / \mathrm{L})$.

Due to its short half-life (19 h), CRP is a reliable marker of systemic inflammatory response secondary to the surgical procedure or even a marker of complications, tending to normalize rapidly with the patient's recovery. Together with clinical signs and other inflammatory markers, CRP has been evaluated as an indicator of an unfavorable postoperative course, including surgical and non-surgical complications.

C-reactive protein (CRP) test is done to check for infection after surgery. CRP levels normally rise within 2 to 6 hours of surgery and then go down by the third day after surgery. If CRP levels stay elevated 3 days after surgery, an infection may be present.

In this series, we observed that from the first postoperative day onwards, mean serum CRP was significantly higher in the group who developed leakage, and this marker remained elevated until the diagnosis of the complication. These results are consistent with others recently published and seem to suggest that the early and sustained elevation of postoperative serum CRP may be used as a predictor of anastomotic leakage in patients in whom other infectious complications (respiratory, urinary tract and surgical wound infections) could be excluded.

C-reactive protein at postoperative days 3 and 5 was a good predictor of anastomotic leak and other postoperative septic complications, showing the highest accuracy among clinical and laboratory data.

The changes observed in postoperative CRP levels in patients who developed leakage demonstrate the presence of an inflammatory process and the activation of hepatic synthesis of CRP immediately after the surgical procedure (and before the occurrence of clinical manifestations). As the synthesis of this inflammatory marker is dependent only on the liver function and not compromised by any other organ failure, the rate of CRP production actually reflects the intensity of the inflammatory process.

In this study, CRP increases in both type of cases (elective and emergency) from their preoperative value to onwards postoperative days 3 and then decreases gradually.

The increase of CRP was marked in leak cases than in cases without leak upto $3^{\text {rd }}$ POD then there was nothing significant difference in value of CRP in both group of cases (cases with leak and cases without leak).

\section{Conclusion}

This study shows that C-reactive protein does increase in cases of anastomotic leakage, but not marked difference was found in mean value of CRP in both group of cases (patients with anastomotic leak and patients without anastomotic leak). Hence, it is not a reliable predictor/indicator of impending anastomotic leak. Therefore only on the basis of value of CRP we can't decide management of patient and also early discharge or further hospital stay. CRP value can be used in conjunction with other clinical parameters for management of patient.

\section{References}

[1] Alves A,Panis Y, Pocard M,RegimbeaubJM,ValleurnP. Management of anastomotic leakage after nondiverted large bowel resection.J Am Coll Surg 1999: 189:554559 [PMID: 10589591]

[2] Bruce J, Krukowski ZH, Al-Khairy G, Russell EM, Park KG. Systematic review of the definition and measurement of anastomotic leak after gastrointestinal surgery. Br J Surg 2001; 88: 1157-1168 [PMID: 11531861 DOI: 10.1046/ j.0007-1323.2001.01829.x]

[3] Karliczek A, Harlaar NJ, Zeebregts CJ, Wiggers T, Baas PC, van Dam GM. Surgeons lack predictive accuracy for anastomotic leakage in gastrointestinal surgery. Int J Colorectal Dis. 2009;24:569-76.

[4] Warschkow R, Beutner U, Steffen T, Müller SA, Schmied BM, Güller U, Tarantino I. Safe and early discharge after colorectal surgery due to C-reactive protein: a diagnostic meta-analysis of 1832 patients. Ann Surg 2012; 256: 245-250 [PMID: 22735714 DOI: 10.1097/SLA.0b013e31825b60f0]

[5] Ortega Deballon P, Ruiz de Adana-Belbel JC, Hernandez-Matias A, Garcia-Septiem J, MorenoAzcoita M. Usefulness of laboratory data in the management of right iliac fossa pain in adults. Dis Colon Rectum. 2008;51:1093-9.

[6] Karamarkovic A, Radekovic D, Milic N, et al. Protein C as an early marker of severe septic complications in diffuse secondary peritonitis. World J Surg. 2005;29:759-65.

[7] Mustard RA, Bohnen JM, Haseeb S, Kasina R. Creactive protein levels predict postoperative septic complications. Arch Surg. 1987;122:69-73.

[8] Clyne B, Olshaker JS (1999). "The C-reactive protein". J Emerg Med 17 (6): 1019-25.

[9] Pepys MB, Hirschfield GM (June 2003)."C-reactive protein: a critical update".J.Clin. Invest.111 (12):180512. doi:10.1172/JCI18921. PMC 161431.PMID 12813013

[10] Mantovani A, Garlanda C, Doni A, Bottazzi B (January 2008). "Pentraxins in innate immunity: from $C$-reactive protein to the long pentraxin PTX3". J. Clin. Immunol. 28 (1): 1-13. doi:10.1007/s10875-007-9126-7. PMID 17828584

[11] NCBI Entrez Protein \#CAA39671

[12] Liu S, Ren J, Xia Q, Wu X,Han G, Ren H, Yan D, Wang G, Gu G, Li J (May 2013). "Preliminary Casecontrol Study to Evaluate Diagnostic Values of CReactive Protein and Erythrocyte Sedimentation Rate in Differentiating Active Crohn's Disease From Intestinal Lymphoma, Intestinal Tuberculosis and Behcet's Syndrome". Am. J. Med. Sci. 346 (6): 46772. doi:10.1097/MAJ.0b013e3182959a18. PMID 23689052

[13] Clyne B, Olshaker JS (1999). "The C-reactive protein". J Emerg Med 17 (6): 1019-25.doi:10.1016/S07364679(99)00135-3. PMID 10595891. 


\section{International Journal of Science and Research (IJSR) \\ ISSN (Online): 2319-7064 \\ Index Copernicus Value (2015): 78.96 | Impact Factor (2015): 6.391}

[14] Welsch, T., Müller, S.A., Ulrich, A., Kischlat, A., Hinz, U., Kienle, P. et al. C-Reactive protein as early predictor for infectious postoperative complications in rectal surgery. Int J Colorectal Dis. 2007; 22: 14991550

[15] Pepys, M.B. and Hirschfield, G.M. C-Reactive protein: a critical update. J Clin Invest. 2003; 111: 1805-1812

[16] Gylys, Barbara A. and Mary Ellen Wedding (2005), Medical Terminology Systems, F.A. Davis Company

[17] Carty N J,Keating J, Campbell J, Karanjia N, Heald R J. Prospective audit of an extramucosal technique for intestinal anastomosis. Br J Surg 1991; 78: 1439 1441.

[18] Fraser I.Intestinal anastomosis with a skin stapler: a safe and efficient method in humans. Br J Surg 1994; 81: $665-667$.

[19] Irwin S T,Krukowski Z H, Matheson N A. Single-layer anastomosis in the upper gastrointestinal tract. $\mathrm{Br} J$ Surg 1990; 77: 643-644.

[20]Lustosa S A,Matos D, Atallah A N, Castro A A. Stapled versus handsewn method for colorectal anastomosis surgery. Cochrane Database Syst Rev 2001; CD 001825.

[21] Sarin S,Lightwood R G. Continuous single-layer gastrointestinal anastomosis: a prospective audit. $\mathrm{Br} \mathrm{J}$ Surg 1988; 155: 611-614.

[22] Steele R J C.Continuous single-layer serosubmucosal anastomosis in the upper gastrointestinal tract. $\mathrm{Br} \mathrm{J}$ Surg 1993; 80: 1416-1417.

[23] Thompson W H F,Robinson M H E. One-layer continuously sutured colonic anastomosis. $\mathrm{Br} \mathrm{J}$ Surg 1993; 80: 1450-1451.

[24] Nozoe T, Matsumata T, Kitamura M, Sugimachi K. Significance of preoperative elevation of serum Creactive protein as an indicator for prognosis in colorectal cancer. Am J Surg

[25] Boccola MA, Buettner PG, Rozen WM, et al. Risk factors and outcomes for anastomotic leakage in colorectal surgery: a single-institution analysis of 1576

[26] Barone JE.Abnormal vital signs not a good indicator of anastomotic leaks. Medscape Medical News [serial online]. March 24, 2014;Accessed April 1, 2014. Available

http://www.medscape.com/viewarticle/82239

[27] Erb L, Hyman NH, Osler T. Abnormal Vital Signs Are Common after Bowel Resection and Do Not Predict Anastomotic Leak. J Am Coll Surg. Feb 28 2014; [Medline

[28] Bellows, C.F., Webber, L.S., Albo, D., Awad, S., and Berger, D.H. Early predictors of anastomotic leaks after colectomy. Tech Coloproctol. 2009; 13: 41-47

[29] Kingham, T.P. and Pachter, H.L. Colonic anastomosis leak: risk factors, diagnosis, and treatment. J Am Coll Surg. 2009; 208: 269-278

[30] Buchs, N.C., Gervaz, P., Secic, M., Bucher, P., Mugnier-Konrad, M., and Morel, P. Incidence, consequences, and risk factors for anastomotic dehiscence after colorectal surgery: a prospective monocentric study. Int J Colorectal Dis. 2008; 23: 265270

[31] Bokey, E.L., Chapuis, P.H., and Fung, C. Postoperative morbidity and mortality following resection of the colon and rectum for cancer. Dis Colon Rectum. 1995; 38: 480-487

[32] Alves, A., Panis, Y., Pocard, M., Regimbeau, J.M., and Valleur, P. Management of anastomotic leakage after nondiverted large bowel resection. J Am Coll Surg. 1999; 189: 554-559

[33] Ortega-Deballon, P., Radais, F., Facy, O., d'Athis, P., Masson, D., Charles, P.E. et al. C-reactive protein is an early predictor of septic complications after elective colorectal surgery. World J Surg. 2010; 34: 808-814

[34] Wong VK, Malik HZ, Hamady ZZ, Al-Mukhtar A, Gomez D, Prasad K, et al. C-reactive protein as a predictor of prognosis following curative resection for colorectal liver metastases. Br J Cancer. 2007;96:222-5. [PMC free article] [PubMed]

[35] Matthiessen P, Henriksson M, Hallböök O, Grunditz E, Norén B, Arbman G. Increase of serum C-reactive protein is an early indicator of subsequent symptomatic anastomotic leakage after anterior resection.Colorectal Dis. 2008;10:75-80. [PubMed]

[36] Welsch T, Frommhold K, Hinz U, Weigand MA, Kleeff $\mathrm{J}$, Friess $\mathrm{H}$, et al. Persisting elevation of C-reactive protein after pancreatic resections can indicate developing inflammatory complications. Surgery.2008;143:20-8. [PubMed]

[37] Welsch T, Müller SA, Ulrich A, Kischlat A, Hinz U, Kienle $\mathrm{P}$, et al. C-reactive protein as early predictor for infectious postoperative complications in rectal surgery. Int J Colorectal Dis. 2007;22:1499-507.[PubMed]

[38] Deitmar S, Anthoni C, Palmes D, Haier J, Senninger N, Brüwer M. Are leukocytes and CRP early indicators for anastomotic leakage after esophageal resection? Zentralbl Chir. 2009;134:83-89. [PubMed]

[39] Woeste, G., Muller, C., Bechstein, W.O., and Wullstein, C. Increased serum levels of C-reactive protein precede anastomotic leakage in colorectal surgery. World J Surg. 2010; 34: 140-146

[40] Welsch, T., Müller, S.A., Ulrich, A., Kischlat, A., Hinz, U., Kienle, P. et al. C-Reactive protein as early predictor for infectious postoperative complications in rectal surgery. Int J Colorectal Dis. 2007; 22: 1499 1507

[41] Millan, M., Garcia-Granero, E., Flor, B., GarciaBotello, S., and Lledo, S. Early prediction of anastomotic leak in colorrectal cancer surgery by intramucosal pH. Dis Colon Rectum. 2006; 49: 595-601

[42] Attard, J.A., Raval, M.J., Martin, G.R., Kolb, J., Afrouzian, M., Buie, WD. et al. The effects of systemic hipoxia on colon anastomotic healing: an animal model. Dis Colon Rectum. 2005; 48: 1460-1470

[43] Shandall, A., Lowndes, R., and Young, H.L. Colonic anastomotic healing and oxygen tension. Br J Surg. 1985; 72:606-609

[44] Sheridan, W.G., Lowndes, R.H., and Young, H.L. Tissue oxygen tension as a predictor of colonic anastomotic healing. Dis Colon Rectum. 1987; 30: 867871

[45] Vignali, A., Gianotti, L., Braga, M., Radaelli, G., Malvezzi, L., and Di Carlo, V. Altered microperfusion at the rectal stump is predictive for rectal anastomotic leak. Dis Colon Rectum. 2000; 43: 76-82

[46] Nozoe T, Saeki H, Sugimachi K. Significance of preoperative elevation of serum $\mathrm{C}$-reactive protein as an 


\section{International Journal of Science and Research (IJSR) \\ ISSN (Online): 2319-7064 \\ Index Copernicus Value (2015): 78.96 | Impact Factor (2015): 6.391}

indicator of prognosis in esophageal carcinoma. Am J Surg 2001; 182: 197-201

[47]Hefler LA, Concin N, Hofstetter G, et al. Serum Creactive protein as independent prognostic variable in patients with ovarian cancer

[48] Sierzega M, Kolodziejczyk P, Kulig J et al. Im $\neg$ pact of anastomotic leakage on long-term survival after total gastrectomy for carcinoma of the stomach. Br J Surg 2010; 97: 1035-42.

[49] Deguchi Y, Fukagawa T, Morita S et al. Identification of Risk Factors for Esophagojejunal Anastomotic Leakage after Gastric Surgery. World J Surg 2012; 36: 1617-1622er. Clin Cancer Res 2008;14:710-4

[50] Park DJ, Lee HJ, Kim HH et al. Predictors of opera $\neg$ tive morbidity and mortality in gastric cancer surgery. Br J Surg 2005; 92: 1099-1102.

[51] Csendes A, Burgos AM, Roizblatt D, et al. Inflammatory response measured by body temperature, C-reactive protein and white blood cell count 1, 3, and 5 days after laparotomic or laparoscopic gastric bypass surgery. Obes Surg 2009; 19: 890-3

[52] de Mello J, Struthers L, Turner R, Cooper EH, Giles GR. Multivariate analyses as aids to diagnosis and assessment of prognosis in gastrointestinal cancer. Br J Cancer 1983;48: 341-8.

[53] Surgery of the liver, biliary tract and pancreas-L.H BLUMGART, 4th edition vol.1, p.n.-697

[54] Werner J, Hartwig W, Uhl W, Müller C, Büchler MW. Useful markers for predicting severity and monitoring progression of acute pancreatitis. Pancreatology 2003;3:115-27.

[55] Wullstein C, Drognitz O, Woeste G, et al. High levels of C-reactive protein after simultaneous pancreaskidney transplantation predict pancreas graft-related complications and graft survival. Transplantation 2004;77:60-4.

[56] Gastrointestinal and Liver disease-STEISENGER \& FORDTRAN"S, 8 th edition ,p. n.-2508

[57](57) Olubuyide IO, Brown NM, Higginson J , Whicher JT-Ann Clin Biochem , 1989 May

[58] Allin KH, Nordestgaard BG (2011). "Elevated Creactive protein in the diagnosis, prognosis, and cause of cancer". Crit Rev Clin Lab Sci 48 (4): 155 70.doi:10.3109/10408363.2011.599831 . PMID 22035340.

[59] Pradhan AD, Manson JE, Rifai N, Buring JE, Ridker PM (July 2001). "C-reactive protein, interleukin 6, and risk of developing type 2 diabetes mellitus". JAMA 286 (3): 327 34.doi:10.1001/jama.286.3.327 . PMID 11466099 .

[60] Dehghan A, Kardys I, de Maat MP, Uitterlinden AG, Sijbrands EJ, Bootsma AH, Stijnen T, Hofman A, Schram MT, Witteman JC (March 2007). "Genetic variation, C-reactive protein levels, and incidence of diabetes". Diabetes 56 (3): 872-8. doi:10.2337/db060922 . PMID 17327459.

[61]Lloyd-Jones DM, Liu K, Tian L, Greenland P (June 2006). "Narrative review: assessment of C-reactive protein in risk prediction for cardiovascular disease" . Ann Intern Med 145(1): 35-42. doi:10.7326/0003-4819145-1-200607040-00129. PMID 16818927.

[62] Verma S, Yeh ET. C-reactive protein and atherothrombosis-beyond a biomarker: an actual partaker of lesion formation. Am J Physiol Regul Integr Comp Physiol. 2003; 285: R1253-R1256.

[63] Szmitko PE, Wang CH, Weisel RD, et al. New markers of inflammation and endothelial cell activation. Circulation. 2003; 108: 1917-1923.

[64] Yeh ET, Willerson JT. Coming of age of C-reactive protein: using inflammation markers in cardiology. Circulation. 2003; 107: 370-372.

[65]Ridker PM. Clinical application of C-reactive protein for cardiovascular disease detection and prevention. Circulation. 2003; 107: 363-369

[66] al-Saigh AH. C-reactive protein in the differential diagnosis of the acute abdomen, especially acute appendicitis. J R Coll Surg Edinb. 1992;37:238-40.

[67] Gurleyik E, Gurleyik G, Unalmiser S. Accuracy of serum C-reactive protein measurements in diagnosis of acute appendicitis compared with surgeon's clinical impression. Dis Colon Rectum. 1995;38:1270-4.

[68] Yang HR, Wang YC, Chung PK, Chen WK, Jeng LB, Chen RJ. Role of leukocyte count, neutrophil percentage, and C-reactive protein in the diagnosis of acute appendicitis in the elderly. Am Surg. 2005;71:344-7.

[69] Gronroos JM. Is there a role for leukocyte and CRP measurements in the diagnosis of acute appendicitis in the elderly? Maturitas. 1999; 31:255-8.

[70] Gronroos JM, Gronroos P. Leukocyte count and Creactive protein in the diagnosis of acute appendicitis. Br J Surg. 1999; 86:501-4.

[71] Erkasap S, Ates E, Ustuner Z, Sahin A, Yilmaz S, et al. Diagnostic value of interleukin-6 